которое обращает к вечным архетипам); обозначает процесс интеллектуализации литературы (её конвергенции с философией и психологией); это роман-миф, созданный художником-мифортворцем, творящим новую реальность, преодолевающим своё время и в своей интертекстуальности обращённый к мировому контексту культуры и поискам сакрального.

$$
* * *
$$

1. Манн Т. Об учении Шпенглера // Манн Т. Собр.соч.: В 10 т. Т.9. М.: ГИХЛ, 1960.

2. Гарин И.И. Век Джойса. М.: Терра, 2002.

3. Мамардашвили М.К. Лекции о Прусте. М., 1995.

4. Пруст М. По направлению к Свану. - М.: Эксмо, 2003.

5. Элиот Т. Улисс, порядок и миф // Элиот Т. Избранное. М.: Терра, 2002.

6. Гессе Г. Избранное: Игра в бисер. М.: Радуга, 1984.

7. Курбатов А.К. Джойс. М.: Молодая гвардия, 2011.

\title{
Миронов М.В. \\ Лексико-семантическая группа «масть лошади» в русско- и англоязычной художественной литературе
}

Государственный Университет «Дубна» (Россия, Дубна)

doi: $10.18411 / s p c-26-11-2017-13$

idsp: 000001:spc-26-11-2017-13

Лошади с давних времен были верными спутниками человека. Искусство, труд, спорт, путешествия, война - без лошадей все это было бы совсем другим. Лошади не утратили своего значения и в современном мире: они до сих пор используются в сельском хозяйстве, при передвижении по труднодоступным районам, в медицине для производства сыворотки против болезней. Конный туризм наряду с иппотерапией обеспечивают человеку необходимый контакт с природой. Лошадь была и остается помощником и спутником человека. Соответственно велико и ее значение в искусстве.

В лингвистике существует интерес к изучению языковой картины мира- это представления о мире, сложившегося у членов языкового коллектива и отражающегося в языке. Лошади играют разную роль в жизни народов. Изучая то, как названия мастей лошадей используются в текстах художественных произведений, можно сделать выводы о значении лошади в языковой картине мира.

В этой статье рассматриваются названия мастей в произведениях русской и английской художественной литературы. Однако, вначале следует сказать несколько слов о составе лексико-семантической группы «масть лошади» в соответствующих языках. Согласно нашему исследованию, в русском языке насчитывается не менее 75 названий мастей. Большинство из них представляет собой сложные слова, состоящие из основного наименования и прилагательного, уточняющего цвет (светло-гнедая, темнорыжая, золотисто-соловая). В дополнение к этому, нами было найдено 49 устаревших названий. В английском языке лексико-семантическая группа включает 122 слова. Основную часть, так же, как и в русском, составляют сложные прилагательные (lightbay, darkchestnut, goldenpalomino).

В качестве материалов для исследования особенностей перевода названий мастей лошадей использовались тексты художественных произведений на русском языке и их переводы на английский язык: «Анна Каренина» (Л.Н. Толстой), «Война и мир» (Л.Н. Толстой), «Холстомер» (Л.Н. Толстой), «Преступление и наказание» (Ф.М. Достоевский), «Мёртвые души» (Н.В. Гоголь).

Также в исследовании рассматривались тексты произведений англоязычных авторов: рассказы «Серебряный» (А.К.Дойль), «Мустанг-иноходец» (Э.СетонТомпсон), повести «Черный Красавчик» (А.Сьюэлл) и «Дымка» (Дж.Виль), трилогия 
«Конец главы» (Дж.Голсуроси), «Боевой конь» (М.Морпурго) и множество романов Д.Фрэнсиса.

В результате сравнения текстов русско- и англоязычных художественных произведений с их переводами было отмечено, что при переводе названий мастей как с русского на английский, так и наоборот, очень часто используются такие переводческие приемы, как генерализация, конкретизация и замена.

При генерализации термин заменяется более общим понятием, например, ср. $H y$, купикауруюкобылу[1] - Well, then buy the chestnut mare [7]. Слово «каурая» обозначает «дикую» рыжую масть, с отметинами. При переводе это слово заменяется на chestnut, что значит просто «рыжая».

При использовании приема конкретизации, термин, наоборот, заменяется более частным понятием. Например, ср. ...муххортая пегая лошадка, известная у лошадиных барышников под именем сороки... [1] - ... a runty piebald horse known among horse traders as a magpie... [7]. Пегая масть подразумевает, что у лошади есть белые пятна. Пегими могут быть лошади разных мастей - вороные, гнедые, рыжие и так далее. Однако, в английском языке для обозначения пегой масти используются два слова piebald, означающее «вороно-пегая» и skewbald, использующееся для обозначения любой другой пегой лошади. Соответственно, в данном примере мы имеем дело с конкретизацией. Нужно отметить, что использование слова skewbald в этом случае было бы ошибкой, ведь речь, как можно понять по упоминанию «сороки», идет именно о вороно-пегой лошади.

Наконец, при замене при переводе используется термин с другим значением. Например, ср. Ятогдамолодыхпристяжныхккауромузапрег[5] - That time I'd harnessed two young side horses with the bay in the shafts[9]. В переводе использовано слово bay, что значит «гнедая». Гнедая и каурая масти заметно различаются.

Сравнивая особенности перевода названий мастей с английского на русский, мы заметили, что использование эпитетов, использующихся для описания мастей, возросло. Cp. coal-black - «черный, как уголь», jet-black - «блестящая вороная»,nightblack - «темная, как ночь»,ghost-white - «точно призрак, светлая»,flamingred - «горел, как огонь». Возможно, это связано с тем, что во многих англоязычных произведениях, выбранных нами, лошади играют важную роль в сюжете - соответственно, их описанию уделяется большое внимание. Например, в рассказе «Мустанг-иноходец» (Э. Сетон-Томпсон), повестях «Черный Красавчик» (А. Сьюэлл) и «Дымка» (Дж. Виль) и романе «Боевой конь» (М. Морпурго) лошади являются главными персонажами. В изученных нами произведениях русской литературы, за исключением повести «Холстомер» (Л.Н. Толстой), лошади играли второстепенную роль.

При переводе русских текстов на английский чаще остальных использовалось название sorrel (светло-рыжая), а при переводе английских книг большинство названий мастей передавались, как «гнедая». Следует также заметить, что в переводе на русский язык чаще используется название караковой масти. Этим термином несколько раз заменялись bay (гнедая), darkbay (темно-гнедая), chestnut (рыжая), sorrel (светлорыжая). Например, ср.:

The next day he was seen with Boar Hound, the kinked-necked sorrel...[10] НаутроонпассярядомсВепрем - караковымжеребиом... [2].

All the rest are dark bay or light brown[6] - Всепрочие - караковыелибогнедые [3].

Two bays and a chestnut [8] -Двегнедых, однакараковая [4].

Pauli had believed me on two counts, first against the chestnut and then for the bау...[6] - Паули поверил мне два раза: в первый раз, когда я отсоветовал ему покупать рыжего, и во второй, когда посоветовал купить каракового.... [3].

Названия мастей в переводимых текстах заменяются с разными целями. Причины использования переводческих приемов могут быть связаны с фонетикой (когда использование эквивалента делает предложение сложным для произнесения) или 
стилистикой (когда термин имеет несколько значений, или является анахронизмом, или же не подходит, например, ввиду своей сложности). Нужно отметить, что в русской литературе чаще используются более конкретные названия, например, каурая, караковая, игреневая. В англоязычных произведениях чаще упоминаются более общие названия, такие, как chestnut (рыжая).

Лексико-семантическая группа «масть лошади» в русском и английском языке представляет богатый материал для исследований, связанных с проблемами категоризации понятий. В лингвистике подробно изучаются названия цветообозначений. Однако, по нашим данным, наименования мастей лошадей в таком качестве рассматриваются впервые.

$$
* * *
$$

1. Гоголь Н. В. Мертвые души. - М.; Л.: Издательство Академии наук СССР, 1951. [Электронный peсурс]. - Режим доступа: (http://rvb.ru/gogol/01text/vol 06/01 mertvye dushi/0132.htm).

2. Д. Виль. Дымка. [Электронный ресурс]. - Режим доступа: (http://elly17.narod.ru/books/dymka.htm\#).

3. Д. Фрэнсис. Сокрушительный удар. [Электронный pecypc]. - Режим доступа: (http://www.ereading.club/bookreader.php/60886/Frensis_-_Sokrushitel\%27nyii_udar.html).

4. Дж. Голсуорси. Конец главы: Через реку. [Электронный ресурс]. - Режим доступа: (http://lib.ru/INPROZ/GOLSUORSI/glava3.txt).

5. Толстой Л. Н. Война и мир. Том 2. - М.: Художественная литература, 1980. [Электронный ресурс]. Режим доступа: (http://rvb.ru/tolstoy/01text/vol 5/0030 2.htm).

6. DickFrancis. KnockDown. [Электронныйресурс]. - Режимдоступа: (http://www.yesnovel.com/knockdown-dick-francis).

7. Gogol N. Dead Souls. Translated and annotated by Richard Pevear and Larissa Volokhonsky. [Электронный pecypc]. Режим доступа: (http://projects.iq.harvard.edu/gov2126/files/gogol_dead_souls_1996.pdf).

8. John Galsworthy. End of the Chapter:Over the River. WebeditionbyeBooks@Adelaide, 2014 [Электронный ресурс]. (https://ebooks.adelaide.edu.au/g/galsworthy/john/over/index.html).

9. Tostoy L. War and Peace. Translated by Louise and Aylmer Maude. WebeditionbyeBooks@Adelaide, 2014 [Электронный $\quad$ pecypc]. (https://ebooks.adelaide.edu.au/t/tolstoy/leo/t65w/complete.html).

10. Will James. Smoky TheCowhorse. [Электронный pecypc]. - Режим доступа: (http://gutenberg.net.au/ebooks07/0700111h.html).

\section{Работкин Ю.В. \\ Категория «дейксиса» в грамматике немецкого языка}

МГУ имени М.В. Ломоносова (Россия, Москва)

doi: $10.18411 / s p c-26-11-2017-14$

idsp: 000001:spc-26-11-2017-14

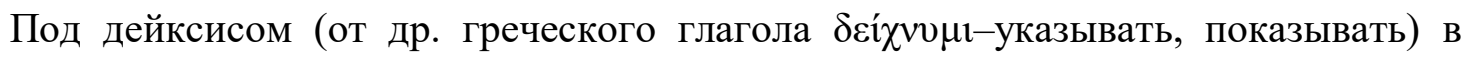
лингвистике понимается указание на положение объекта в пространстве и/или времени относительно «дейктического центра» (я - здесь - сейчас), связанного с речевым актом[4]. Категория дейксиса, несмотря на ее важную роль в устной и письменной коммуникации, не всегда рассматривается в современных немецких грамматиках как самостоятельная категория [13], а иногда и вообще не упоминается в них $[10,15,17,20$, $21,22]$, что, с одной стороны, связано с многообразием и разнородностью лексикограмматических средств ее выражения, а с другой - разницей в теоретических подходах к описанию языковыхкатегорий $[18,23]$. Категория дейксиса иногда рассматривается как прагматическая категория [19], а не грамматическая, т.к. она связывает элементы системы языка с системой речи [2: 244].

В истории лингвистической мысли представлены расширенная и узкая трактовки этого понятия. В узком понимании дейксиссвязан с локализацией объектов и ориентиром в ситуации относительно места и времени актуального высказывания говорящего/их. Такое понимание категории дейксиса восходит к работам 